\title{
FRANÇOIS MITTERRAND WOBEC ROZPADU JUGOSŁAWII W LATACH 1991-1995
}

\author{
MAREK MIKOŁAJCZYK
}

\begin{abstract}
Marek Mikołajczyk, François Mitterrand wobec rozpadu Jugosławii w latach 1991-1995 (François Mitterrand to the disintegration of Yugoslavia, 1991-1995).

Balcanica Posnaniensia. Acta et studia, XX, Poznań 2013, Wydawnictwo Instytutu Historii UAM, pp. 195-216, ISBN 978-83-63047-36-1, ISSN 0239-4278. Polish text with a summary in English.

Marek Mikołajczyk, Uniwersytet im. Adama Mickiewicza, Instytut Historii, ul. Św. Marcin 78, 61-809 Poznań.
\end{abstract}

W roku 1981, a więc w momencie objęcia najwyższego urzędu w państwie, w oczach Francuzów socjalista François Mitterrand bardziej uchodził za polityka, który interesował się trzecim światem aniżeli Europą. To jego pokonany rywal, dotychczasowy prezydent Francji Valery Giscard d'Estaing cieszył się opinią polityka zaangażowanego w sprawy europejskie ${ }^{1}$. Jak twierdzi Claude Cheysson, minister spraw zagranicznych Mitterranda w latach 1981-1984, nowy prezydent interesował się Europa, o ile związane to było bezpośrednio z problemami wewnętrznymi Francji ${ }^{2}$. $\mathrm{Z}$ kolei jeden $\mathrm{z}$ najbliższych doradców francuskiego prezydenta Hubert Védrine uważa, że w dziedzinie polityki zagranicznej Mitterrand nie był technokratą, ani też działaczem socjalistycznym czy też utopijnym moralistą. Na scenie międzynarodowej był pragmatykiem, francuskim politykiem, geografem i historykiem zafascynowanym ideą długiego trwania Fernanda Braudela, Francuzem z prowincji ukształtowanym w kulturze klasycznej ${ }^{3}$.

Obejmując najwyższy urząd w państwie Mitterrand miał sprecyzowany pogląd na temat fundamentów francuskiej polityki zagranicznej. Zaliczał do nich niezależność narodową, równowagę sił między blokami w świecie, budowę Europy, prawo

\footnotetext{
${ }^{1}$ P. Favier, M. Martin-Roland, La décennie Mitterrand, t. I : Les ruptures (1981-1984), Paris 1990, s. 267.

2 Tamże, s. 270.

${ }^{3}$ H. Védrine, Les mondes de François Mitterrand. À l’Élysée 1981-1995, Paris 1996, s. 84-86.
} 
narodów do samostanowienia oraz rozwój państw biednych ${ }^{4}$. Uważał, że historia jest wynikiem położenia geograficznego, dlatego tak dużą wagę przywiązywał do analiz geostrategicznych. Bliskie mu było stwierdzenie Napoleona I, że każdy kraj ,prowadzi politykę swojej geografii" "5 . Europa nie była dla niego zwykłym zestawieniem obcych sobie narodów. Był przekonany, że w różnych okresach swoich dziejów, Europa istniała na różnych płaszczyznach: sztuki, wiary, badań, rozumu, idei. Przypominał, że w roku 1500 na terenie całej Europy działało około 60 uniwersytetów. Kariera Erazma z Rotterdamu, który wykładał w Paryżu, Anglii, na uniwersytetach włoskich, była wyrazem istnienia już wówczas Europy. Wielkie ruchy liberalne czy też kontrrewolucyjne obejmowały swoim zasięgiem niemalże całą Europę w XIX i XX wieku. Nie wątpił, że Europejczycy mieli wspólne korzenie ${ }^{6}$.

Źródeł jugosłowiańskiego konfliktu należałoby się doszukiwać w wydarzeniach, jakie rozegrały się na Bałkanach na przełomie XIX i XX wieku, kiedy to na gruzach imperium otomańskiego narody bałkańskie sięgały po niepodległość, tocząc między sobą spory, a nawet konflikty zbrojne. Rozwiązania przyjęte po I wojnie światowej tylko pozornie rozwiązywały problem Bałkanów. Lata II wojny światowej pokazały, że podziały na Bałkanach nadal pozostawały bardzo głębokie. Doświadczyła tego Jugosławia, której narody walczyły po obu stronach konfliktu.

Po II wojnie światowej, w celu osłabienia silnej pozycji Serbii, w jej ramach powstały dwie autonomiczne jednostki, a mianowicie Wojwodina oraz Kosowo i Metochia. Należy też zwrócić uwagę na fakt, iż od kilku stuleci poważny odsetek Serbów występował w takich historycznych krajach, jak Bośnia i Hercegowina, Wojwodina, Chorwacja czy Dalmacja. Rosnąca wrogość między Serbami, a mieszkańcami pozostałych republik, zwłaszcza Chorwatami, stała się jednym ze źródeł późniejszego konfliktu. Do tego należy dodać pogłębiające się różnice w rozwoju gospodarczym między bogatymi i biednymi republikami oraz konflikt religijny między katolikami, wyznawcami prawosławia i muzułmanami. Marszałek Josip „Broz” Tito w okresie swoich długoletnich rządów silnej ręki wymusił w miarę sprawne funkcjonowanie federacji jugosłowiańskiej. Po jego śmierci w roku 1980 dawne konflikty odżyły z całą moca, zwłaszcza konflikt między separatystycznymi dążeniami Chorwatów i hegemonistycznymi aspiracjami Serbów.

Mitterrand uczestniczył w uroczystościach pogrzebowych jugosłowiańskiego przywódcy jako szef Partii Socjalistycznej. Na czele francuskiej delegacji stał premier Raymond Barre. Po raz kolejny Mitterrand był w Jugosławii w roku 1983. Już wówczas był informowany o pogarszającej się sytuacji w tym kraju, zwłaszcza o rosną-

\footnotetext{
${ }^{4}$ F. Mitterrand, Réflexions sur la politique extérieure de la France. Introduction à vingt-cinq discours (1981-1985), Paris 1986, s. 7.

${ }^{5}$ T. Schabert, Mitterrand et la réunification allemande. Une histoire secrète (1981-1995, Paris 2002, s. 346-347.

${ }^{6}$ Wystapienie przez Zgromadzeniem Parlamentarnym Rady Europy w dniu 30 września 1982 r.; F. Mitterrand, Onze discours sur l'Europe (1982-1995), Paris 1995, s. 14.
} 
cych napięciach między poszczególnymi republikami na tle narodowym ${ }^{7}$. We Francji nie spodziewano się jednak, że doprowadzić to może do rozpadu państwa. Widziano w tym raczej przejściowy kryzys. Pierwsze poważniejsze ostrzeżenia świadczące o pogarszającej się sytuacji w Jugosławii francuscy obserwatorzy zaczęli dostrzegać w roku $1988^{8}$. Pogłębiający się kryzys w tym kraju długo nie był jednak dostrzegany przez francuskiego prezydenta. Jugosławia nie była strategicznie ważnym obszarem, nie dysponowała również cennymi surowcami.

Rozpad państwa jugosłowiańskiego po roku 1989 przyspieszyło pogorszenie się sytuacji gospodarczej oraz postępujący kryzys społeczno-polityczny. W roku 1990 w wyniku wolnych wyborów w poszczególnych republikach do władzy doszły partie nacjonalistyczne opowiadające się za samodzielnością. Szczególnie widoczne było to w Chorwacji, gdzie władzę przejął były generał Tity Franjo Tudjman oraz w Słowenii, gdzie na pozycje nacjonalistyczne przeszedł rządzący tam dotychczas były przywódca Związku Komunistów Słowenii, Milan Kučan. Z kolei na czele republiki serbskiej stanął komunista Slobodan Milošević, opowiadający się za utrzymaniem Jugosławii, między innymi po to, aby Serbowie pozostali nadal w jednym państwie. Ideologię komunistyczną we wszystkich republikach zastępowano nacjonalizmem. W wielonarodowej i wielokulturowej Bośni przewagę zdobyli Muzułmanie, z którymi zaczęto identyfikować narodowość bośniacką. Alija Izetbegović - prezydent Bośni w latach 1990-1996, był oskarżany o hołdowanie islamskiemu fundamentalizmowi ${ }^{9}$.

Mitterrand zakładał, że dzięki reformom uda się zachować Jugosławię w całości. Był przekonany, że nie ma lepszego rozwiązania dla narodów Jugosławii, jak utrzymanie tego państwa, być może w nieco zmienionej formie. Mówił o tym chociażby podczas spotkania z prezydentem Federacji Jugosłowiańskiej Borisavem Joviciem w listopadzie 1990 roku, który poinformował go o wewnętrznych sporach i postępującym rozpadzie państwa. Mitterrand stwierdził wówczas: „Pragniemy, by Jugosławia pozostała Jugosławią. Nie jest pożądanym, by istniejące kraje rozpadły się na kilka kawałków"10. Dodał również, że Francja nie będzie wspierać takich ruchów, ale też zastrzegł, że niewiele może zrobić $\mathrm{w}$ tej sprawie ${ }^{11}$.

Francuski prezydent, odnosząc się do przyczyn konfliktu w Jugosławii, nie krył się ze swoją sympatią do Serbów: „Lubię Serbów, tak, i co z tego? Jak zapomnieć ich odwagę podczas dwóch wojen?"'12. To poparcie Mitterranda dla Serbów miało kilka źródeł. Jednym z nich była dość jednostronna wiedza historyczna prezydenta o na-

7 J. Lacouture, Mitterrand. Une histoire de Français, t 2: Les vertiges du sommet, Paris 1998, s. 409.

${ }^{8}$ H. Védrine, Les mondes, s. 594-595.

${ }^{9}$ D. Wybranowski, Między niepodległościq a dezintegracja. Bośnia i Hercegowina w XX $i$ XXI wie$k u$, Szczecin 2012, s. 186.

10 H. Védrine, Les mondes, s. 604.

11 P. Favier, M. Martin-Roland, La décennie Mitterrand, t. 4 : Les déchirements (1992-1995), Paris 1999, s. 211.

12 Cyt. za : L. Adler, L'Année des adieux, Paris 1995, s. 77. 
rodach Jugosławii w czasie II wojny światowej, wsparta jego osobistym doświadczeniem. Serbów uważał za bohaterów, którzy w latach II wojny światowej przeciwstawili się niemieckiej okupacji. Był przekonany, że okupację tę wspierali natomiast Chorwaci. W rzeczywistości problem ten był dużo bardziej złożony. Po stronie Tity stanęło również wielu Chorwatów. Z kolei nacjonaliści serbscy związani z ruchem czetnickim generała Dragoljuba „Dražy” Mihajlovicia w latach II wojny światowej nie reprezentowali jednolitego stanowiska wobec okupantów. Część kolaborowała z Niemcami (Kosta Pećanac), z drugiej strony przywódca tzw. ruchu rawnogorskiego Dragoljub „Draža” Mihajlović był zwolennikiem orientacji prozachodniej. Jego koncepcja zakładała jednak bierne stanowisko wobec okupantów. Ponadto w obliczu walki z komunistami dochodziło do taktycznych porozumień między prozachodnimi czetnikami a dowódcami wojsk okupacyjnych ${ }^{13}$.

Nie bez znaczenia dla pozytywnej oceny Serbów ze strony prezydenta Francji było także i to, że znalazł się on w niemieckiej niewoli w roku 1940 wraz z jeńcami serbskimi. Po latach Mitterrand wspominał, że byli oni traktowani jak zwierzęta, chociaż zasługiwali na największy szacunek ${ }^{14}$. Na proserbskie opinie Mitterranda wpływ miało również przekonanie, że Serbowie jako jedyni są politycznie zdolni do zaprowadzenia porządku w federacji jugosłowiańskiej. Jego krytycy zarzucali mu, że nie wyobrażał sobie Jugosławii w innej formie niż federacja ${ }^{15}$. Prezydent Francji obawiał się też wzmocnienia wpływów niemieckich w tej części Europy. Niemcy wyraźnie wspierali Chorwatów i Słoweńców w ich dążeniu do niepodległości, co jeszcze bardziej umacniało Mitterranda w przekonaniu o potrzebie udzielenia poparcia Serbom. Należy zauważyć, że proserbskie nastawienie Mitterranda miało pokaźne grono zwolenników we Francji, gdzie często przypominano, że w konflikcie, który na początku XX wieku wstrząsną Bałkanami i doprowadził do wybuchu I wojny światowej, Francja wraz z Rosją stanęła po stronie Serbów przeciwko Austro-Wegrom i Niemcom ${ }^{16}$. Serbowie mogli liczyć na poparcie francuskich polityków wywodzących się z różnych opcji politycznych.

Mimo poważnych rozbieżności w ocenie sytuacji na terenie Jugosławii oraz wyraźnego podziału sympatii, Mitterrand i Kohl przez pewien okres czasu gotowi byli ze sobą współpracować w sprawie Jugosławii, by nie dopuścić do eskalacji konfliktu. 29 maja 1991 roku prezydent Francji oraz kanclerz Niemiec zwrócili się ze wspólnym apelem do władz Jugosławii, w którym wyrazili głęboki niepokój w związku z rozwojem sytuacji w tym kraju. Pogłębiający się konflikt, który już doprowadził do śmierci wielu osób, stanowi bowiem zagrożenie dla stabilności nie tylko dla regionu, ale też dla całej Europy. Obaj przywódcy przypomnieli działania Wspólnoty Europejskiej, zmierzające do powstrzymania konfliktu. Potwierdzili swoje wcześniejsze stanowi-

${ }^{13}$ M. J. Zacharias, Jugosławia w polityce Wielkiej Brytanii 1940-1945, Wrocław 1985, s. 49-50.

14 Wypowiedź z roku 1995, J. Lacouture, op. cit., s. 408.

${ }^{15}$ Y. Brossard, J. Vidal, L'éclatement de la Yugoslavie de Tito. Désintégration d'une fédération et guerres interethniques, Québec 2001, 134-135.

16 Tamże, s. 134. 
sko, że jedynie pokojowy dialog oparty na demokracji i ścisłym przestrzeganiu praw człowieka oraz gwarancji dla mniejszości może zapewnić przyszłość Jugosławii ${ }^{17}$. Mimo wspólnej deklaracji już wówczas dochodziły sygnały, że Kohl rozważa możliwość zrezygnowania z obrony integralności państwa jugosłowiańskiego ${ }^{18}$.

25 czerwca 1991 roku Słowenia i Chorwacja ogłosiły niepodległość. Współpraca francusko-niemiecka w sprawie konfliktu w Jugosławii została poddana bardzo poważnej próbie. Podczas szczytu państw Wspólnoty Europejskiej w Luksemburgu Mitterrand, wspierany przez pozostałych przywódców Wspólnoty, opowiedział się przeciwko jednostronnym deklaracjom niepodległości. Przypomniał o konieczności poszanowania integralności terytorialnej poszczególnych republik oraz prawach mniejszości. Jako jedyny francuskiego stanowiska w sprawie republik Jugosławii nie poparł kanclerz Kohl, który opowiedział się za prawem narodów Jugosławii do samostanowienia. Słuchając wystappienia kanclerza, Mitterrand wypisywał na kartce wszystkie narody, które mogłyby się ubiegać o ustanowienie własnego państwa. Doliczył się ich aż $17^{19}$. Ostatecznie państwa Wspólnoty zapowiedziały, że nie uznają nowych republik na podstawie jednostronnych decyzji o niepodległości. Stanowisko to miało poparcie Stanów Zjednoczonych.

Tymczasem w odpowiedzi na krok Słowenii i Chorwacji, władze federacyjne Jugosławii już 27 czerwca rozpoczęły zbrojną interwencję przeciwko obu republikom. Państwa Wspólnoty Europejskiej 29 czerwca na szczycie w Luksemburgu podjęły decyzję o wysłaniu swoich przedstawicieli do Zagrzebia, by doprowadzić do wstrzymania walk. Mitterrand uważał, że wysłannicy ci powinni też przypomnieć władzom w Belgradzie, że kraje Wspólnoty opowiadają się za jednością Jugosławii i jeśli walki będą kontynuowane, to wstrzymana zostanie pomoc. Po przybyciu na miejsce, przedstawiciele Wspólnoty Europejskiej zaproponowali, by Słowenia i Chorwacja tymczasowo zawiesiły decyzję o niepodległości. W zamian za to oczekiwali, że wojska federacyjne wrócą do koszar. Po ich powrocie Mitterrand oświadczył, że jedynie rozwiązania prawne, a nie siłowe, mogą powstrzymać poszczególne republiki od pójścia W stronę autonomii ${ }^{20}$.

Pod naciskiem państw Wspólnoty, na początku lipca doszło do porozumienia między Chorwatami, Słoweńcami i Serbami w sprawie zawieszenia broni. Działania w Słowenii wygasły po kilku dniach, ale wojna rozpoczęła się na dobre w Chorwacji. W wyniku walk, które trwały do końca 1991 roku zginęło tam około 10 tys. Ucierpiały miasta chorwackie, przede wszystkim Vukovar i Dubrownik. 12 lipca Jacques Blot, dyrektor departamentu Ministerstwa Spraw Zagranicznych ds. Europy, zdając relację z kilkudniowego pobytu w Jugosławii, informował, że w opinii wszystkich jego roz-

17 P. Jardin, A. Kimmel, Les relations franco-allemands depuis 1963, Paris 2001, s. 393.

18 Niemiecki kanclerz rozmawiał o tym z premierem Wielkiej Brytanii J. Majorem; H. Védrine, Les mondes, s. 605.

19 Zdarzenie to opisuje R. Dumas, Le Fil et la Pelote. Mémoires, Paris 1996, s. 353.

20 P. Favier, M. Martin-Roland, op. cit., t. 4, s. 209-210. 
mówców nie ma już podstaw do dalszego istnienia Jugosławii jako federacji, gdyż każda ze stron szykuje się na wojnę ${ }^{21}$.

Mitterrand, w przeciwieństwie do Kohla, nie spieszył się z uznaniem Chorwacji i Słowenii, gdyż przeciwny był „dzikiej” niepodległości. Opowiadał się za kontynuowaniem dialogu i przeciwny był jakiejkolwiek interwencji zbrojnej, by nie dopuścić do wybuchu wojny ${ }^{22}$. W tym czasie w Paryżu, poza dialogiem, rozważane były również dwa inne rozwiązania. Pierwsze z nich miało polegać na użyciu sił policyjnych, co oznaczałoby dla Francji konieczność wysłania od 500 do 2000 żołnierzy. Drugie rozwiązanie przewidywało wysłanie sił europejskich w ramach Unii Zachodnioeuropejskiej (UZE) w celu oddzielenia walczących stron. Wybór tego rozwiązania spowodowałby konieczność wysłania przez Francję około 10 tys. żołnie$\mathrm{rzy}^{23}$. Mitterrand był przeciwny obu tym propozycjom. W sierpniu 1991 roku, podczas posiedzenia rządu, prezydent stwierdził, że państwa Wspólnoty Europejskiej nie są w stanie podjać interwencji, gdyż nie mają na to środków. ZSRR także nie będzie interweniować z uwagi na problemy wewnętrzne. I dodał: „Nie możemy zapominać o tradycyjnych przyjaźniach. Dla nas, jak i dla Rosji, jest to Serbia. Słowenia i Chorwacja są raczej zwrócone w stronę Germanów. Konkludując, sprawa jest bardzo poważna i nie uda się jej załatwić"24.

Mitterrand w coraz większym stopniu był przekonany, że nie można narzucić federacji siłą. Obawiał się jednak, że rozpad Jugosławii może doprowadzić zamieszkujące tam narody do dramatu ${ }^{25}$. Dlatego też niepokoiła go postawa Kohla, który gotów był uznać nowe republiki i wprowadzić sankcje przeciwko Serbom, o ile rozejm nie zostanie utrzymany. $\mathrm{W}$ celu lepszego zapoznania się $\mathrm{z}$ sytuacji na terenie Jugosławii, pod koniec sierpnia Mitterrand spotkał się w Paryżu z prezydentem Chorwacji Tudjmanem i prezydentem Serbii Miloševiciem ${ }^{26}$. Spotkania te można uznać za pewien przełom w polityce Mitterranda wobec Jugosławii, gdyż w ten sposób dawał do zrozumienia, że jego rozmówcami nie są już tylko władze federacyjne, ale również władze jej republik. W czasie rozmów z obu przywódcami prezydent starał się jak najwięcej dowiedzieć na temat rozwoju wydarzeń na terenie Jugosławii. Chciał też poznać ich intencje. Chorwacki prezydent ostro zaatakował Serbów, oskarżając ich o wolę przywrócenia komunizmu, do czego Mitterrand odniósł się z dużym dystansem. Tudjman domagał się uznania niepodległości Chorwacji. Francuski prezydent zapewnił go, że granice Chorwacji zostaną uznane aktem międzynarodowym, jeśli Chorwaci uznają prawa 12\% Serbów mieszkających w Chorwacji, głównie w Krajinie i Slawonii. Z kolei rozmowa Mitterranda z Miloševiciem rozpoczęła się od przypomnienia przez obu przywódców tradycyjnych więzów przyjaźni łączących

21 Tamże, s. 216.

22 Wypowiedź z 24 lipca 1991 r. Podczas posiedzenia rządu, P. Favier, M. Martin-Roland, op. cit., t. 4 , s. 216.

23 Tamże, s. 216-217.

24 R. Dumas, Le Fil et la Pelote, s. 354.

25 H. Vedrine, Les mondes, s. 463-465.

${ }^{26}$ H. Védrine, Les mondes, s. 398 ; P. Favier, M. Martin-Roland, op. cit., t. 4, s.219-22. 
Serbię i Francję. W czasie spotkania francuski prezydent opowiedział się za prawem narodów do samostanowienia, z czym Milošević się zgodził w przypadku Chorwacji i Słowenii, ale jednocześnie zastrzegł, że mieszkańcy pozostałych republik, to znaczy Serbii, Bośni i Czarnogóry nie chcą opuścić Jugosławii. Serbski prezydent oskarżył Chorwatów o zamiar wprowadzenia faszyzmu, co raczej rozbawiło Mitterranda, który dzień wcześniej usłyszał chorwackie zarzuty pod adresem Serbów na temat komunizmu. Milošević zaprzeczył, by to armia federalna prowadziła działania zbrojne w Chorwacji. Zapewnił, że jej rola polega na oddzielaniu stron konfliktu. Mitterrand podkreślił, że tego konfliktu nie da się rozwiązać na drodze zbrojnej. Oczekiwał zgody na międzynarodowy arbitraż. Mimo że obaj przywódcy obiecali wprowadzenie zawieszenia broni, to Mitterrand nie miał jednak większych złudzeń, że obietnica ta zostanie dotrzymana.

7 września 1991 roku Wspólnota Europejska zwołała konferencję pokojową do Hagi z udziałem wszystkich stron konfliktu. Na stanowisko rozjemcy powołano szefa brytyjskiej dyplomacji lorda Petera Carringtona. Jednakże jego propozycja utrzymania luźnej federacji suwerennych narodów Jugosławii została ostatecznie odrzucona przez Serbów, którzy obawiali się, że otwiera ona drogę do autonomii Albańczyków z Kosowa.

Problem Jugosławii był przedmiotem rozmów w czasie francusko-niemieckiego spotkania na szczycie w dniach 18-19 września. Mitterand ostrzegł Kohla przed prowadzeniem własnej polityki na Bałkanach, gdyż może to doprowadzić do rozłamu w łonie Wspólnoty Europejskiej. Wyraził jednocześnie gotowość wypracowania wspólnego kompromisu. Kohl zgodził się z tym, że konflikt na Bałkanach nie może doprowadzić do sporów między państwami Wspólnoty, gdyż mogłoby to doprowadzić do porażki szczytu w Maastricht w sprawie przyjęcia traktatu o Unii Europejskiej. Kanclerz obiecał, że nie będzie podejmował jednostronnych decyzji w sprawie konfliktu.

Ostatecznie obaj przywódcy we wspólnej deklaracji wyrazili zaniepokojenie w związku z pogłębieniem się konfliktu w Jugosławii, który każdego dnia prowadzi do śmierci i wygnania wielu cywilów. Zdecydowanie potępili użycie siły i wezwali do natychmiastowego zaprzestania rozlewu krwi, przypominając o porozumieniu w sprawie zawieszenia broni, do którego zawarcia doszło za sprawą lorda Carringtona. Oznajmili ponadto, że Wspólnota Europejska nie uzna żadnych granic, które zostaną ustanowione $\mathrm{w}$ oparciu o przemoc. Wezwali również do zaprzestania dostaw broni dla walczących stron. Opowiedzieli się za prawem narodów do samostanowienia oraz przestrzeganiem praw mniejszości narodowych. Zaproponowali zwołanie konferencji pokojowej, która miałaby doprowadzić do zaprzestania walk i rozwiązania kwestii spornych ${ }^{27}$.

W tym samym czasie rząd w Paryżu proponował, by Unia Zachodnioeuropejska rozważyła możliwość wysłania do Jugosławii sił pokojowych. Żaden kraj nie był jednak zainteresowany wysłaniem swoich wojsk w ten region Europy. Po nieudanych pró-

${ }^{27}$ H. Védrine, Les mondes, s. 399. 
bach rozwiązania konfliktu jugosłowiańskiego podejmowanych przez kraje Wspólnoty Europejskiej, Francja postanowiła przenieść go na forum Rady Bezpieczeństwa ONZ. Mitterrand wysłał swojego ministra spraw zagranicznych do Nowego Jorku z propozycją rezolucji w sprawie wysłania do Chorwacji sił ONZ mających wymusić przestrzeganie zawieszenia broni ${ }^{28}$. Przeciwko tej propozycji wystapiły jednak Stany Zjednoczone. Amerykanie dali jasno do zrozumienia, że nie wyślą swoich żołnierzy do Jugosławii, gdyż sprzeciwi się temu amerykańska opinia publiczna. Amerykanie postrzegali wojnę w Jugosławii jako kryzys regionalny, w którym ich żywotne interesy w żaden sposób nie były zagrożone. $Z$ uwagi na brak porozumienia wielkich mocarstw w sprawie wojny w Jugosławii, Rada Bezpieczeństwa podjęła jedynie decyzję o wprowadzeniu embarga na dostawy broni dla walczących stron.

Widząc brak reakcji ze strony społeczności międzynarodowej, Serbowie pod koniec września 1991 roku zintensyfikowali działania zbrojne w Chorwacji. Rozpoczęli oblężenie Dubrownika i przystapili do decydującego szturmu na Vukovar. To 45-tysięczne miasto leżące we wschodniej Slawonii nad Dunajem było zamieszkiwane w większości przez Chorwatów, ale Serbowie stanowili około $32 \%$ jego mieszkańców $^{29}$. Przewaga w walce o Vukovar była zdecydowanie po stronie serbskiej, która liczyła kilkukrotnie więcej żołnierzy. Ponadto wojska serbskie były dużo lepiej wyposażone.

Mitterrand obawiał się dalszej eskalacji konfliktu w Jugosławii po wejściu w życie decyzji o niepodległości Chorwacji i Słowenii. Decyzja ta została zawieszona 7 lipca na okres trzech miesięcy. 2 października francuski prezydent spotkał się w Paryżu z prezydentem Słowenii Milanem Kučanem. Niepodległość Słowenii nie była problemem dla Mitteranda, gdyż kraj ten zamieszkiwany był niemalże w całości przez Słoweńców. Obawiał się jednak, że uznanie niepodległości Słowenii pociaggnie za sobą decyzję o niepodległości Chorwacji, gdzie sytuacja narodowościowa była dużo bardziej skomplikowana z uwagi na mniejszość serbską ${ }^{30}$. Mitterrandowi nie udało się odwieść Słoweńców od ogłoszenia niepodległości. Kraj ten ogłosił niepodległość 8 października. Tego samego dnia uczyniła to także Chorwacja. W odpowiedzi na ten krok wojska serbskie ostrzelały stolicę Chorwacji Zagrzeb. Ambasada francuska w Belgradzie otwarcie pisała o wojnie ${ }^{31} .17$ listopada w ręce Serbów wpadł Vukovar. Po zajęciu miasta oddziały serbskie dopuściły się wielu okrucieństw, które wstrząsnęły opinią międzynarodową. Celem serbskich ataków było zajęcie obszarów zamieszkałych przez ludność serbską i przyłączenie ich do Republiki Serbskiej (Српска Република Босна и Херчеговина), proklamowanej na terenie Bośni i Hercegowiny

28 P. Favier, M. Martin-Roland, op. cit., t. 4, s. 270-271.

29 Według spisu ludności z 1991 r., gminę Vukovar zamieszkiwało 84189 mieszkańców z czego Chorwacji stanowili 43,8\% (36 910), Serbowie 37,4\% (31 445), Węgrzy 1,6\% (1 375), a ci, którzy określali siebie jako Jugosłowianie 7,3\% (6 124). Inne narodowości stanowiły 9,9\% (8 335). W samym mieście Vukovar mieszkało 21065 Chorwatów (47,2\%) i 14425 Serbów (32,3\%); A. Nazor, Grad je bio meta: bolnica, dom umirovljenika, Zagreb 2008, s. 37.

30 P. Favier, M. Martin-Roland, op. cit., t. 4, s. 272-273.

31 Tamże, s. 273. 
w kwietniu 1992 roku ${ }^{32}$. W odpowiedzi na serbskie ataki, kraje Wspólnoty ogłosiły wprowadzenie sankcji gospodarczych przeciwko Serbii. Mitterrand przyznał, że Europa nie dysponowała innymi środkami oddziaływania przeciwko walczącym stronom. Nie uważał jednak, by to była porażka Wspólnoty ${ }^{33}$.

Okrucieństw na ludności cywilnej dopuszczały się wszystkie strony konfliktu. W toku walk od marca 1992 roku do sierpnia 1995 roku zginęło około 200 tys. osób, z czego aż 95 \% stanowili cywile ${ }^{34}$. Mitterrand zdawał się jednak nie dostrzegać zbrodni popełnianych przez Serbów, mimo informacji dostarczonych mu przez ministra ds. pomocy humanitarnej Bernarda Kouchnera, który przebywał w Dubrowniku i na własne oczy widział skutki serbskich działań. W wywiadzie udzielonym 29 listopada niemieckiemu dziennikowi „Frankfurter Allgemeine Zeitung”, Mitterrand odmówił uznania winy Serbów. Podkreślił, że historia Serbii i Chorwacji od dawna przepełniona jest dramatami. W czasie II wojny światowej wielu Serbów zginęło w obozach chorwackich. To Chorwaci, a nie Serbowie byli po stronie nazistów. Przekonywał, że Serbia prowadzi wojnę nie po to, by zająć Chorwację, ale by przejąć kontrolę, pośrednią lub bezpośrednią, nad ludnością serbską zamieszkującą ten kraj. Jego zdaniem do rozwiązania konfliktu na terenie Jugosławii konieczny był międzynarodowy arbitraż. Podkreślił, że jest przeciwny jednostronnym deklaracjom o niepodległości ze strony Chorwacji i Słowenii.

Innego zdania był Bernard Kouchner, który ostrzegał, że Europa, nie robiąc nic w obronie Dubrownika, wystawia na szwank swoją wiarygodność. Opowiadał się też za jak najszybszym uznaniem Chorwacji, gdyż przyczyniłoby się do wzmocnienia jej pozycji na arenie międzynarodowej i stanowiłoby przeciwwagę dla Serbów ${ }^{35}$.

15 listopada Mitterrand po raz kolejny rozmawiał z kanclerzem Kohlem o uznaniu niepodległości Chorwacji i Słowenii. I po raz kolejny przypomniał, że państwa Wspólnoty powinny prowadzić spójną politykę w tej kwestii. Warunkiem wstępnym ewentualnego uznania niepodległości obu republik powinna być gwarancja granic oraz poszanowanie praw mniejszości. Ostrzegał, że uznanie Chorwacji będzie błędem. Kohl zdawał sobie $\mathrm{z}$ tego sprawę, ale jednocześnie mówił o silnej presji, jaką wywierają na niego jego partia oraz koalicyjna FDP, a także Kościół, media i 500 tys. Chorwatów mieszkających w Niemczech ${ }^{36}$.

Stanowisko niemieckie w sprawie uznania niepodległości Słowenii i Chorwacji w coraz większym stopniu niepokoiło francuskiego prezydenta. Był on przekonany, że Niemcy będą chcieli zrealizować ten cel na szczycie w Maastricht. 2 grudnia w czasie rozmowy z premierem Wielkiej Brytanii Johnem Majorem, Mitterrand ostrzegał, że uznanie Chorwacji nie powstrzyma Serbów przed dalszym prowadzeniem wojny, chyba że z pomocą Chorwacji przyjdą Niemcy i Włosi, a to oznaczać

32 A. Czubiński, Europa w XX wieku, Poznań 2001, s. 396.

${ }^{33}$ P. Favier, M. Martin-Roland, op. cit., t. 4, s. 274.

3422 lutego 1993 roku Rada Bezpieczeństwa ONZ powołała do życia specjalny trybunał międzynarodowy do osądzenia osób oskarżonych o zbrodnie wojenne w Jugosławii; A. Czubiński, op. cit., s. 396.

35 Tamże, s. 276.

${ }^{36}$ H. Védrine, Les mondes, s. 615-616. 
już będzie prawdziwą wojnę $e^{37}$. Jeszcze tego samego dnia o problemie niepodległości Chorwacji i Słowenii Mitterrand rozmawiał także z Kohlem. Przed tym spotkaniem francuski prezydent został powiadomiony przez Rolanda Dumasa, że Niemcy nie wystąpią z żądaniem uznania niepodległości obu tych państw na szczycie w Maastricht. Uczynią to natomiast jednostronnie między 16 a 24 grudnia, o czym zapewnił go Genscher. W czasie rozmowy z Kohlem Mitterrand ostrzegł, że uznanie niepodległości Słowenii i Chorwacji bez międzynarodowych gwarancji niczego nie zmieni, zwłaszcza nie powstrzyma Serbów przed dalszymi atakami na Chorwację. Francuski prezydent po raz kolejny przestrzegal, że sprawa ta może doprowadzić do niebezpiecznych podziałów w łonie Wspólnoty. Kohl mówił z kolei o bardzo poważnych wewnętrznych naciskach ze strony niemieckiej opinii publicznej i klasy politycznej w sprawie uznania niepodległości obu tych państw. Nie wierzył też w międzynarodowe porozumienie w tej kwestii. Ostatecznie obaj rozmówcy ustalili, że do tematu powrócą po zakończeniu szczytu w Maastricht ${ }^{38}$.

Kohl słowa dotrzymał i sprawa Jugosławii nie pojawiła się na szczycie w Maastricht. Na temat niepodległości Słowenii i Chorwacji mieli się wypowiedzieć ministrowie spraw zagranicznych państw „dwunastki” w dniu 16 grudnia. Dumas sugerował Mitterrandowi, by ustapił Kohlowi, gdyż najwyżej może on odwlec decyzję o uznaniu niepodległości o kilka dni. Czy warto z tego powodu ryzykować podziałami wewnątrz Wspólnoty? - pytał szef francuskiej dyplomacji. Mitterrand był jednak innego zdania. W liście skierowanym do Kohla 15 grudnia po raz kolejny przedstawił swoje obawy związane ze skutkami uznania niepodległości Słowenii i Chorwacji. Liczył się przede wszystkim z dalszym rozprzestrzenienia się konfliktu. Wskazał również na konieczność zachowania wspólnego stanowiska Wspólnoty w tej kwestii, a zwłaszcza jedności francusko-niemieckiej. Zaproponował, by prezydenci Chorwaci i Słowenii na spotkaniu z państwami Wspólnoty zobowiązali się do przestrzegania granic i praw mniejszości, wprowadzenia instytucji demokratycznych i kontynuowania rozmów pokojowych. Dopiero wówczas wszystkie kraje Wspólnoty mogłyby równocześnie uznać ich niepodległośćc ${ }^{39}$.

Kohl odrzucił jednak propozycje Mitterranda i jeszcze tego samego dnia zapowiedział uznanie Chorwacji i Słowenii niezależnie od stanowiska pozostałych państw Wspólnoty Europejskiej. Decyzja ta miała wejść w życie z dniem 23 grudnia, a więc tuż przed świętami, co Kohl już wcześniej obiecał niemieckim katolikom. Decyzja Kohla wywołała euforię w Słowenii i Chorwacji. Europejscy sojusznicy Niemiec, zwłaszcza Francja, byli skonsternowani. Powodów do zadowolenia nie miały też Stany Zjednoczone, które próbowały bez powodzenia powstrzymać ambicje kanclerza Kohla. Jak pisze Jadwiga Kiwerska, wpływ na decyzje Niemiec miało wielowiekowe oddziaływanie kultury niemieckiej na tym obszarze. Była ona również wyrazem rosnącego poczucia siły i rangi zjednoczonych Niemiec, które, stając się normalnym

\footnotetext{
${ }^{37}$ P. Favier, M. Martin-Roland, op. cit., t. 4, s. 278.

38 Tamże, s. 280.

39 Tamże, s. 281.
} 
krajem, starały się wyartykułować swoje narodowe interesy nie tylko gospodarcze, ale również polityczne ${ }^{40}$.

16 grudnia ministrowie spraw zagranicznych państw Wspólnoty Europejskiej, postawieni przed faktem dokonanym przez stronę niemiecką, wyrazili zgodę na uznanie niepodległości wszystkich republik po spełnieniu przez nie określonych warunków dotyczących przestrzegania praw człowieka i praw mniejszości ${ }^{41}$. Ostatecznie 15 stycznia 1992 roku niepodległość Chorwacji i Słowenii została uznana przez państwa Wspólnoty Europejskiej, a także Austrię, Polskę i Węgry. W kwietniu tego samego roku uczyniły to Stany Zjednoczone, Rosja i Chiny.

Rozdźwięk między Francją a Niemcami w sprawie Jugosławii był głęboki, ale nie na tyle głęboki, by mógł zagrozić relacjom między obu krajami. Nie chcieli tego ani jedni, ani drudzy. Jak zapewnia Jacques Delors, który z niepokojem przyglądał się temu sporowi, widząc w nim zagrożenie dla prac nad traktatem o Unii Europejskiej, oba kraje starały się unikać pogłębiania sporu, by nie dopuścić do poważniejszego kry$\mathrm{zysu}^{42}$. Potwierdza to również szef niemieckiej dyplomacji Hans-Dietrich Genscher, podkreślając, że solidne partnerstwo między obu krajami oraz silne więzi międzyludzkie pozwoliły uniknąć najgorszego ${ }^{43}$.

Problem Jugosławii był jednym z tematów posiedzenia francuskiego rządu w dniu 5 maja 1992 roku. Mitterrand powiedział wówczas: „Wiedzieliśmy od początku, że Jugosławia nie przetrwa, ale nie chcieliśmy przyspieszać wydarzeń. To było celem francuskiej polityki przez cały czas" ${ }^{\prime 4}$. Swoje stanowisko tłumaczył obawą przed rozpadem imperiów, w wyniku czego nieprzygotowane do tego narody sięgały po niepodległość. W przypadku Jugosławii szczególnie skomplikowana była kwestia mniejszości, zwłaszcza mniejszości serbskiej. Problem ten dotyczył wszystkich republik za wyjątkiem Słowenii, która była niemalże jednolita narodowościowo. Przypomniał, że Serbia była w przeszłości sojusznikiem Francji. Żalił się na Niemców, iż to ich działania w dużym stopniu doprowadziły do takiego rozwoju sytuacji ${ }^{45}$.

Uznanie niepodległości Chorwacji i Słowenii nie pozostało bez konsekwencji dla dalszego rozwoju konfliktu w Jugosławii. 29 lutego 1992 roku odbyło się referendum w Bośni w sprawie niepodległości. Zostało ono zbojkotowane przez bośniackich Serbów, którzy zażądali włączenia wschodniej Bośni do tzw. nowej Jugosławii stworzonej z Serbii i Czarnogóry pod koniec kwietnia 1992 roku. Referendum przyniosło zwycięstwo zwolennikom niepodległości Bośni i Hercegowiny. Z decyzją tą nie pogodzili się bośniaccy Serbowie. 1 marca ich oddziały, wspierane przez władze Jugosławii, przystąpiły do działań zbrojnych, zrywając tym samym rozejm wypracowany na początku roku przez byłego amerykańskiego sekretarza stanu Cyrusa

\footnotetext{
40 J. Kiwerska, Świat w latach 1989-2004. Wydarzenia-konflikty-procesy, Poznań 2005, s. 84.

41 Tamże, s. 84.

42 J. Delors, Mémoires, Paris 2004, s. 354.

43 Wypowiedź z roku 1998, J. Lacouture, op. cit., s. 412.

44 Cyt. za : R. Dumas, Coups et blessures. 50 ans de secrets partagés avec François Mitterrand,

45 Tamże, s. 420.
} Paris 2011, s. 420. 
Vance'a. 6 kwietnia 1992 roku Serbowie na kontrolowanym przez siebie obszarze Bośni proklamowali separatystyczne państwo na czele z Radovanem Karadžiciem i przystapili do czystek etnicznych. W odpowiedzi na działania Serbów w Bośni, 7 kwietnia Wspólnota Europejska uznała niepodległość tej republiki. Był to akt moralnego wsparcia dla Bośniaków walczących z serbską agresją ${ }^{46}$. Jak przyznał Mitterrand, emocje wzięły górę nad rozumem ${ }^{47}$.

Los Bośni miał być jednym z przedmiotów czerwcowych obrad europejskich przywódców w Brukseli w czerwcu 1992 roku. W przeddzień tego spotkania Mitterrand oznajmił szefowi francuskiej dyplomacji, iż jest bardzo wstrzą́nięty sytuacja panująca na terenie Bośni, zwłaszcza blokadą lotniska w Sarajewie. Miasto to było praktycznie odcięte od świata. Zapowiedział, że chciałby wystąpić z jakąś spektakularną inicjatywą. Być może będzie to wizyta w Belgradzie albo Sarajewie. Uważał, że trzeba wyjść z utartych ścieżek klasycznej dyplomacji. Chciał, by sprawa ta pozostała ściśle tajna. Przewidywał, że taka inicjatywa mogłaby mieć miejsce po zakończeniu europejskiego szczytu w Lizbonie wyznaczonego na 26-27 czerwca. Chciał, by podczas tej wizyty towarzyszył mu Bernard Kouchner ${ }^{48}$. Wybór Kouchnera, a nie ministra spraw zagranicznych czy obrony, miał być jasnym sygnałem świadczącym o humanitarnym, a nie politycznym charakterze prezydenckiego wyjazdu.

W Lizbonie Dumas i Mitterrand ustalili, że celem wizyty będzie Sarajewo. Wyjazd taki wymagał jednak drobiazgowych przygotowań i trudno byłoby utrzymać go w tajemnicy, na czym Mitterrandowi bardzo zależało. Dlatego też Dumas zaproponował, by przekazać informację odpowiednim służbom, że to minister spraw zagranicznych planuje lot do Sarajewa. Szczegóły tego wyjazdu przygotował sam Mitterrand podczas obrad szczytu. Na kartce papieru, którą przekazał ministrowi spraw zagranicznych, znalazło się około dwudziestu spraw do załatwienia. O swoim wyjeździe zamierzał powiadomić m.in. lorda Carringtona, Cyrusa Vance'a, kanclerza Kohla oraz prezydenta Portugalii Mario Soaresa. W Sarajewie francuski prezydent zamierzał się spotkać z prezydentem Bośni Aliją Izetbegoviciem.

Problem Bośni był przedmiotem obrad szczytu w Lizbonie. Do interwencji zbrojnej w celu uwolnienia lotniska w Sarajewie wezwał premier Włoch Andreotti. Po jego wystapieniu głos zabrał prezydent Francji, który długo mówił o sytuacji w Jugosławii. W swoim przemówieniu podkreślił, że nie można się ograniczać do tradycyjnej dyplomacji i wezwał do podjęcia działań, by ten stan rzeczy zmienić. Zapowiedział, że Francja gotowa jest to uczynic ${ }^{49}$. Mitterrand w ostatniej chwili poinformował kanclerza Kohla oraz gospodarza szczytu Mario Soaresa, iż zamierza osobiście udać się samolotem do Sarajewa. O wizycie Francuzów poinformowany został także prezydent Milošević. Dano mu jednak do zrozumienia, że chodzi o wizytę szefa francuskiej dyplomacji. Milošević uznał ją za niebezpieczną i zaproponował najpierw przylot do

\footnotetext{
46 J. Kiwerska, Świat w latach 1989-2004, s. 85.

${ }^{47}$ Wypowiedź z roku 1994, J. Lacouture, op. cit., s. 417.

48 Tamże, s. 421.

${ }^{49}$ R. Dumas, Le Fil et la Pelote, s. 359.
} 
Belgradu, a następnie przelot helikopterem do Sarajewa tak, jak to było w przypadku ministra spraw zagranicznych Rosji Andrieja Kozyriewa ${ }^{50}$. O wizycie powiadomiony został również prezydent Bośni, któremu także powiedziano, że chodzi o ministra spraw zagranicznych. Izetbegović uznał ten gest za akt wielkiej odwagi godny Francji ${ }^{51}$.

Wsiadając do samolotu w towarzystwie Bernarda Kouchnera, Mitterrand powiedział: „Przeżyjemy mocne i ważne chwile dla Europy. Udajemy się do Sarajewa. Cel mojego wyjazdu jest humanitarny, chcę rozbić blokadę Serbów i nic więcej, żadnych ukrytych celów politycznych (... ). Europa nie będzie się rozwijać, jeśli Sarajewo upadnie" 52 .

Samolot z prezydentem na pokładzie nie mógł jednak wylądować w nocy w Sarajewie. Lotnisko nie było do tego przygotowane. Mitterrand był z tego powodu niezadowolony, gdyż zamierzał spędzić noc w stolicy Bośni ${ }^{53}$. Ostatecznie podjęto decyzję o lądowaniu w chorwackim Splicie, gdzie miejscowe władze starały się odwieść francuską delegacją od dalszego lotu do Sarajewa. Mitterrand nie zmienił jednak zdania. W nocy miały miejsce intensywne konsultacje między Paryżem i Belgradem w sprawie uwolnienia pasa startowego na lotnisku w Sarajewie. Władze serbskie wyraziły na to zgodę. Rano do Splitu wysłane zostały z Paryża dwa helikoptery. W jednym z nich miejsce zajął prezydent wraz z Kouchnerem i pozostałymi członkami delegacji. Drugi helikopter miał ochraniać francuską delegację. Został on ostrzelany podczas podejścia do lądowania przez serbską artylerię. Ale helikopter z prezydentem na pokładzie wylądował bezpiecznie. Mógł to zobaczyć cały świat dzięki telewizyjnemu przekazowi. Była niedziela, 28 czerwca. W związku z tym od razu nasuwa się pytanie, czy decyzja o przybyciu do Sarajewa tego właśnie dnia była dziełem przypadku. Roland Dumas, ówczesny szef francuskiej dyplomacji, zapewnia po latach, że termin przyjazdu Mitterranda do Sarajewa był zbiegiem okoliczności ${ }^{54}$. Należy jednak pamiętać, że to 28 czerwca 1914 roku właśnie w Sarajewie zamordowany został następca tronu Austro-Węgier arcyksiążę Franciszek Ferdynand Habsburg. Zamach ten zapoczątkował serię wydarzeń, które w ciagu kilku tygodni doprowadziły do wybuchu I wojny światowej. Zabójca księcia, Serb Gawriło Princip, uważany był w Sarajewie za bohatera, zarówno przez Serbów, jak i Bośniaków. Dnia 28 czerwca obchodzi się także rocznicę bitwy na Kosowym Polu, która miała miejsce $\mathrm{w}$ roku $1389^{55}$. Bitwa ta odegrała wielką rolę w kształtowaniu się świadomości narodowej Serbów i jest to dla nich dzień szczególny.

50 Dumas, Coups et blessures, s. 429.

51 J. Lacouture, op. cit., s. 420.

52 Tamże, s. 420.

53 R. Dumas, Coups et blessures, s. 433.

54 Tamże, s. 434.

55 Bitwa na Kosowym Polu miała miejsce 15 czerwca. Ponieważ jednak cerkiew serbska stosuje nadal kalendarz juliański, w przeliczeniu na kalendarz gregoriański w XX i XXI wieku rocznica przypada 28 czerwca wg kalendarza gregoriańskiego. 
$\mathrm{Na}$ lotnisku w Sarajewie Mitterrand został powitany przez szefa oddziałów ONZ kanadyjskiego generała Mackenzie, który poinformował go, że jacyś serbscy przywódcy chcą się z nim spotkać. Mitterand chciał jednak najpierw porozmawiać z Bośniakami. Kiedy doszło do jego spotkania z Izetbegoviciem, obaj przywódcy byli wzruszeni. W czasie wizyty w szpitalu, gdzie znajdowali się ranni, Mitterrand usłyszał z ust bośniackiego prezydenta prawdziwy akt oskarżenia pod adresem Serbów i ich metod wojennych na terenie Bośni. Bośniacki przywódca mówił o serbskich obozach koncentracyjnych dla Bośniaków i oczekiwał od Mitterranda interwencji zbrojnej. Ale w czasie krótkiej konferencji prasowej Mitterrand przypomniał, że cel jego wizyty jest ściśle humanitarny, a nie militarny. Sprecyzował, że chce doprowadzić do otwarcia lotniska w Sarajewie dla pomocy humanitarnej.

Mitterrand był gorąco witany na ulicach miasta przez jego mieszkańców. Nadano mu tytuł honorowego obywatela Sarajewa. Można było zobaczyć transparenty z napisem po francusku: „Dziękujemy, panie prezydencie”. Przed pałacem prezydenckim zgromadziło się kilkaset osób, które wznosiły okrzyki „Vive la France ! „, ” Mitterrand - Bosnia! ,.

Francuski prezydent spotkał się także z przedstawicielami władz utworzonej w Bośni Republiki Serbskiej. Na zdjęciach z lotniska w Sarajewie widać go, między innymi, w towarzystwie Radovana Karadžicia i Ratko Mladicia. Bośniaccy Serbowie starali się go przekonać, iż to nie Bośniacy, ale oni cierpią znacznie bardziej: „Na jednego zabitego Bośniaka przypada stu Serbów"- powiedział jeden z nich, były dziekan Wydziału Lekarskiego. Mitterrand słowa te uznał za ponury żart.

W samolocie podczas drogi powrotnej Kouchner starał się skłonić Mitterranda do interwencji zbrojnej, o ile serbskie bomby będą nadal spadać na Sarajewo. Ten jednak odparł, że nie można odpowiadać wojną na wojnę. Tylko naiwni, kłamcy i kilku nawiedzonych intelektualistów może w to wierzyć. Uważał, że także Serbia ma prawo do życia, nie tylko Bośnia. Nadal sceptycznie podchodził do zarzutów wobec Serbów o prowadzenie czystek etnicznych ${ }^{56}$.

Oceniając tę niespodziewaną wizytę francuskiego prezydenta w Sarajewie, „The New York Times" pisał, że chciał on pokazać, poprzez ten zaskakujący wyjazd, że jego cierpliwość wobec Serbów jest na wyczerpaniu i że państwa europejskie nie potrzebują Stanów Zjednoczonych, by prowadzić śmiałą akcję dyplomatyczną. Amerykański dziennik nie wierzył, że misja francuskiego prezydenta przyspieszy działania pokojowe na Bałkanach. Widział w tym raczej gest mający wpłynąć na wewnętrzną politykę Francji, która miała zagłosować w referendum nad traktatem z Maastricht. Opinię tę zdają się potwierdzać słowa rzecznika Pałacu Elizejskiego Jeana Musitelliego, który powiedział, że zdaniem prezydenta należy szybko rozwiązać konflikt jugosłowiański, ponieważ wpływa on negatywnie na wizerunek Europy i może powstrzymać ostateczne przyjęcie traktatu z Maastricht. Gazeta przytacza też wypowiedzi, z których wynika, iż Mitterrand postanowił zrewidować swoją dotychczasową politykę wobec

\footnotetext{
${ }^{56}$ Wyprawa do Sarajewa jest znana z przekazów telewizyjnych i prasowych. Wielokrotnie mówił też o niej i pisał B. Kouchner; Ce que je crois, Paris 1995.
} 
Serbów, by dać im wyraźnie do zrozumienia, że nie może już dłużej tolerować prowadzonej przez nich wojny. W artykule przypomniano, że już na szczycie w Lizbonie Mitterrand po raz pierwszy publicznie ostro potępił działania Serbów ${ }^{57}$. Z kolei następnego dnia ten sam dziennik pisał o politycznym teatrze i chęci udowodnienia Waszyngtonowi, że Europy zdolna jest do działania w czasie, gdy Francja uważa, że maleją wpływy Stanów Zjednoczonych na kontynencie, który nie jest już podzielony przez zimną wojnę ${ }^{58}$.

Czy prezydencka podróż do Sarajewa była bezpieczna ? Na to pytanie odpowiedzi udzielił towarzyszący Mitterrandowi fotograf Claude Azoulay ${ }^{59}$. Kiedy dowiedział się od samego prezydenta w Lizbonie o celu planowanej podróży, uznał to za szaleństwo, gdyż Sarajewo było oblegane przez oddziały samozwańczej Republiki Serbskiej, kraj znajdował się w stanie wojny, a oni mieli dysponować jednym samolotem i kilkoma członkami ochrony. Kiedy dotarli do Splitu, prezydent, z którym zajadali się owocami, powiedział, że może spać choćby na ziemi, o ile ma coś pod głowę. Przypomina też, że jeden z dwóch helikopterów, którymi udali się ze Splitu do Sarajewa, został ostrzelany tuż przed lotniskiem, na którym powitali ich zaskoczeni żołnierze sił UNPROFOR. Prezydent wsiadł wraz z cywilami do opancerzonego transportera, którym poruszał się po zniszczonym i opustoszałym mieście. Tuż przed wylotem na lotnisko spadły jeszcze pociski.

Zaskakująca wyprawa Mitterranda do Sarajewa nie była li tylko spektakularnym gestem, który wzbudził zaskoczenie i podziw niemalże całego świata. Przyniosła bowiem wymierne skutki. Na początku lipca otwarto most powietrzny, dzięki któremu można było dostarczyć towary pierwszej potrzeby dla oblężonego przez Serbów bośniackich Sarajewa. Na Bałkany zostały też wysłane siły NATO w ramach mandatu ONZ, które miały kontrolować przestrzeganie sankcji narzuconych nowej Jugosławii. Ale dla Bośniaków z Sarajewa było to zdecydowanie za mało. Ich entuzjazm spowodowany wizytą francuskiego prezydenta szybko ustąpił miejsca głębokiemu rozczarowaniu. Czuli się pozostawieni na pastwę serbskiej agresji bez jakiegokolwiek wsparcia. Pomoc humanitarna nie rozwiązywała ich problemów. Chcieli walczyć z bronią w ręku o uwolnienie miasta i kraju spod serbskiej okupacji ${ }^{60}$. Mieli też pretensje do Mitterranda, że nie powiadomił świata o zbrodniach serbskich i serbskich obozach koncentracyjnych. Chociaż miał na ten temat wiele informacji, w tym od francuskiego ambasadora w Zagrzebiu, nie sprawdził ich. Kilka tygodni po jego wizycie telewizja brytyjska pokazała wstrząsający materiał z tych obozów.

Przed zbliżającymi się wyborami parlamentarnymi w roku 1993, opozycja uczyniła z wojny w Jugosławii jeden z przedmiotów ataków przeciwko Mitterrandowi. Prezydenta zaatakował m.in. Jacques Chirac, który 10 sierpnia 1992 roku wezwał

57 «The New York Times », 28 czerwiec 1992.r.

58 "The New York Times", 29 czerwiec 1992 r.

59 «Le Nouvel Observateur », 5 styczeń 2006 r.

${ }^{60} \mathrm{Z}$ bośniacką oceną wizyty Mitterranda w Sarajewie można się zapoznać na stronie http://www. dzana.net/55-mitterrand-sarajevo.html. 
Europę i Stany Zjednoczone do podjęcia ograniczonych działań zbrojnych przeciwko Serbom. Przywódca opozycyjnej partii Rassemblement pour la République negatywnie ocenił dotychczasową politykę Francji w tej kwestii. Zarzucił Mitterrandowi nadmierną sympatię wobec Serbów, w czym widział historyczny błąd ${ }^{61} \mathrm{Z}$ apelem w sprawie użycia sił zbrojnych przeciwko Serbom zwrócił się także pierwszy sekretarz Partii Socjalistycznej, były premier Laurent Fabius, który uchodził za ulubieńca prezydenta. Jego wystapienie musiało być dla Mitterranda niemiłym zaskoczeniem $^{62}$.

Kilka dni później Mitterrand, broniąc w wywiadzie prasowym swojego dotychczasowego stanowiska przeciwko interwencji, przypomniał, że żaden kraj nie wystąpił z taką propozycją. Nie uczyniły tego ani Stany Zjednoczone ani Wielka Brytania ${ }^{63}$. Ta wypowiedź natychmiast spotkała się z atakami ze strony przywódców opozycji. Jacques Chirac oskarżył Mitterranda o współudział w prowadzeniu wojny zaborczej i zbrodniach ${ }^{64}$. Na posiedzeniu rządu Mitterrand w ostrych słowach odniósł się do zarzutów ze strony opozycji: „Musimy postawić opozycji prawdziwe pytania: w jaki sposób chcecie, by Francja zaangażowała się militarnie? Wysyłając 100 tys. ludzi, w tym poborowych, żeby zdobyli Belgrad? Żeby chronić Sarajewo? Czy Francja ma interes narodowy w takim przedsięwzięciu?"65.

Postawę Mitterranda w sprawie konfliktu w Bośni w tym czasie dobrze ilustruje też spór, do jakiego doszło w grudniu 1992 roku między nim a panią minister ds. budownictwa mieszkalnego Marie-Noelle Lienemann. Na posiedzeniu rządu zabrała ona głos, by powiedzieć, że w sprawie Bośni dyplomacja nie wystarczy i należy podjąć działania zbrojne przeciwko Serbom tak, jak uczyniono to przeciwko Irakowi w obronie Kuwejtu. Odpowiadając jej Mitterrand, z właściwą sobie ironią, przypomniał, że pani minister, która tak bardzo pragnie wojny z Serbią, jeszcze niedawno była przeciwna wojnie przeciwko Irakowi. I dodał: „Zawsze trzeba patrzeć dalej niż czubek własnego nosa, nie ulegać chwilowym impulsom, nawet jeśli wydają się uzasadnione biorąc pod uwagę straszne obrazy, które nam się pokazuje”. Mitterrand pytał też: „Czy jesteśmy gotowi wziąć na siebie odpowiedzialność kosztowną w pieniądzach i życiu ludzkim? Zobaczylibyśmy, jak szybko opinia publiczna zmienia zdanie. Nie zachowujemy się jak ci, którzy każdego ranka ogłaszają, że idą na wojnę i nic nie robia, ponieważ nic nie mogą zrobić" 66 .

Na początku grudnia 1992 roku podczas spotkania z Kohlem Mitterrand stwierdził, że nie chce prowadzić wojny z Serbią, chociaż był całkowicie przekonany o ich winie. Uważał jednak, że Francja nie dysponuje wystarczającymi środkami do prowadzenia takiej wojny. Jego zdaniem jedynym rozwiązaniem powinno być porozumie-

\footnotetext{
61 P. Favier, M. Martin-Roland, op. cit., t. 4, s. 349.

62 Tamże, s. 349.

63 « Sud-Ouest », 13 sierpień 1992 r.

64 « Le Figaro », 14 sierpień 1992 r.

65 H. Védrine, Les mondes, s. 636.

66 R. Dumas, Coups et blessures, s. 443-444.
} 
nie między wszystkimi stronami konfliktu ${ }^{67}$. Kilka tygodni później w rozmowie z socjalistycznym tygodnikiem „Vendredi” prezydent przypomniał raz jeszcze o swoim sprzeciwie przeciwko użyciu siły. Zapowiedział jednak, że gotów byłby zmienić zdanie, gdyby stanowisko to znalazło poparcie Narodów Zjednoczonych ${ }^{68}$.

W sprawę konfliktu na Bałkanach zaangażowało się wielu francuskich intelektualistów, którzy oczekiwali od prezydenta Francji, że odegra on główną rolę w jego rozwiązaniu. W swoich wypowiedziach kierowali się często emocjami, chociaż pojawiały się także zarzuty pod ich adresem, że chcą wykorzystać ten konflikt dla lansowania się mediach, by zwiększyć sprzedaż swoich książek. Nie ulega wątpliwości, że niektórzy z nich byli manipulowani przez zwalczające się strony, które były bardzo aktywne w Paryżu. Filozofowie André Glucksman i Alain Finkielkraut wzywali do obrony Chorwacji. W swoich wypowiedziach często zarzucali Mitterrandowi nadmierne pobłażanie Serbom. Z kolei Bernard Henri-Lévy (BHL), również filozof, wspierał Bośniaków i ich prezydenta w walce przeciwko Serbom bośniackim ${ }^{69}$. Pozytywnie ocenił on wizytę Mitterranda w Sarajewie, gdyż dzięki niej francuski prezydent pokazał jak można złamać serbską blokadę. W styczniu 1993 roku, po spotkaniu Mitterranda z Izetbegoviciem, którego sam był inicjatorem, pisał o porozumieniu między oby przywódcami w sprawie możliwości zniesienia embarga na dostawę broni dla Bośni. Takiego porozumienia jednak nie było. Podczas wspólnej kolacji Mitterrand zdecydowanie rozwiał nadzieje filozofa, mówiąc: „Za mojego życia nigdy, niech mnie pan słucha, nigdy Francja nie będzie prowadzić wojny przeciwko Serbii”. Rozczarowany postawą Mitterranda, BHL 11 marca zorganizował w Paryżu manifestacje przeciwko przybyciu prezydenta jugosłowiańskiej Republiki Serbii Slobodana Miloševicia do Francji. Przybyło na nią zaledwie 300-400 osób, mimo że do udziału w niej wzywało wiele francuskich organizacji. Manifestujący krzyczeli: „Milošević zbrodniarz! Mitterrand wspólnik !" 70 .

Jeszcze dalej w atakach przeciwko polityce Mitterranda na Bałkanach poszedł francuski slawista Paul Garde, autor wielu książek poświęconych Bośni oraz ekspert przed międzynarodowych trybunałem w Hadze do spraw zbrodni w byłej Jugosławii. Podczas programu Laure Adler Le Cercle de Minuit w lutym roku 1996, a więc już po śmierci Mitterranda, powiedział, że gdyby Mitterrand wcześniej opuścił Pałac Elizejski, to udałoby się uratować życie 100-200 tysięcy Bośniaków ${ }^{71}$.

W sierpniu 1992 roku z inicjatywy ONZ i Wspólnoty Europejskiej rozpoczęto negocjacje pokojowe w sprawie Bośni, którym ze strony ONZ przewodził Cyrus Vance, a ze strony Wspólnoty Europejskiej lord David Owen. Zaproponowany przez nich plan, zwany planem Vance'a - Owena, zawierał zarys prawnoustrojowy nowego państwa z trzema konstytucyjnie uznawanymi i równoprawnymi narodami: serbskim,

\footnotetext{
67 P. Favier, M. Martin-Roland, op. cit., t. 4, s. 353.

68 „Vendredi”, 22 stycznia 1993 r.

${ }^{69} \mathrm{Na}$ temat sporu między Mitterrandem i BHL pisze m.in. „L'Express”, 10 styczeń 2005 r.

70 Tamże.

71 http://www.ina.fr/histoire-et-conflits/autres-conflits/video/CPB96002049/special-bosnie.fr.html
} 
muzułmańskim i chorwackim. Plan ten został przedstawiony na początku stycznia 1993 roku. Nie został jednak przyjęty przez wszystkie strony konfliktu i tym samym plan ten nie mógł wejść w życie. Głównym przedmiotem sporu była kwestia podziału Bośni i Hercegowiny.

Stany Zjednoczone oraz główne mocarstwa europejskie nie zdecydowały się jednak na użycie siły, by zmusić walczące strony do zawarcia pokoju. Ograniczono się do deklaracji i prób mediacji oraz zaostrzenia sankcji gospodarczych przeciwko nowej Jugosławii. Szczególnie niechętne ewentualnej interwencji zbrojnej Stanów Zjednoczonych na Bałkanach była Francja oraz Wielka Brytania, które obawiały się o losy swoich żołnierzy służących w jednostkach UNPROFOR w Bośni z ramienia ONZ. Takiego poparcia natomiast gotowe były udzielić Niemcy. W marcu 1993 roku, w rozmowie z nowo wybranym prezydentem Stanów Zjednoczonych Billem Clintonem, Mitterrand potwierdził swój sprzeciw wobec ewentualnego udziału francuskich sił w konflikcie bałkańskim. Podkreślił, że nie zamierza wystawić ich na niebezpieczeństwo wojny partyzanckiej. Przekonywał, że Bośniacy potrzebują wojny międzynarodowej, świętej wojny, gdyż jest to elementem ich gry ${ }^{72}$.

W marcu 1993 roku socjaliści przegrali wybory parlamentarne. Po raz drugi w okresie prezydentury Mitterranda do władzy doszła opozycja. Rolanda Dumasa na czele ministerstwa spraw zagranicznych zastapił Alain Juppé, który wcześniej wielokrotnie w ostrych słowach krytykował politykę Mitterranda i socjalistów na Bałkanach. Nowy szef francuskiej dyplomacji, wspierany przez ministra obrony François Léotarda, zapowiedział podjęcie bardziej energicznych kroków w celu rozwiązania bałkańskiego konfliktu. Szybko jednak obaj ministrowie musieli się zmierzyć z rzeczywistością. Zdali sobie sprawę z ewentualnych skutków takich działań. Wezwanie do podjęcia zdecydowanych kroków przeciwko Serbom napotkało też poważny opór ze strony proserbsko nastawionych najwierniejszych spadkobierców polityki generała de Gaulle'a ${ }^{73}$. Tak więc nowy rząd, mimo wcześniejszych obietnic, nie wprowadził radykalnej zmiany w polityce Francji na Bałkanach. Zmienił się co prawda jej ton, który stał się bardziej energiczny, ale nie poszły za tym czyny. Mitterrand był zadowolony z tego stanu rzeczy i pozytywnie wyrażał się o nowym ministrze spraw zagranicznych, podkreślając, że Francja w sprawie Bałkanów mówi jednym głosem.

W dniu 4 maja François Mitterrand spotkał się z amerykańskim sekretarzem stanu Warrenem Christopherem w celu omówienia sytuacji na Bałkanach. Obaj zgodzili się, że ewentualne bombardowanie terenów zajmowanych przez Serbów bośniackich miałoby jedynie wówczas sens, gdyby towarzyszyła temu odpowiednia akcja na ziemi. To jednak nie wchodziło w rachubę. Zamiast tego strona amerykańska proponowała częściowe zniesienie embarga na dostawę broni dla muzułmanów, by mogli się bronić. Mitterrand przyznał, że z moralnego punktu widzenia taka decyzja miałaby

\footnotetext{
72 J. Lacouture, op. cit., s. 423.

73 Tamże, s. 424.
} 
uzasadnienie. Jednakże obawiał się, że jej skutkiem byłaby eskalacja działań zbrojnych ze strony Serbów ${ }^{74}$.

Na zakończenie szczytu francusko-niemieckiego, który miał miejsce w Beaune w dniach 1-2 czerwca 1993 roku oba kraje poparły plan Vance'a- Owena w sprawie integralności terytorialnej i suwerenności Bośni i Hercegowiny oraz wezwały do przestrzegania zawieszenia broni. Potępiły bombardowanie ludności muzułmańskiej oraz akty gwałtu bez względu na to, kto był ich sprawcą. Uznały za konieczne utworzenie strefy bezpieczeństwa dla ochrony ludności bośniackiej. Potwierdziły też konieczność utrzymania w mocy sankcji przeciwko Serbii do czasu wypełnienia przez nią warunków przyjętych w rezolucji 820 ONZ z 17 kwietnia 1993 roku. Oba kraje wezwały także wspólnotę międzynarodową do wzmożenia wysiłków w celu niedopuszczenia do rozprzestrzenienia się konfliktu na inne obszary Jugosławii ${ }^{75}$.

Brak międzynarodowej reakcji w sprawie Bośni doprowadził do dalszego pogorszenia się sytuacji w tym kraju. Szczególnie dramatyczne wydarzenia miały miejsce w Sarajewie, które od jesieni 1993 roku znajdowało się pod ostrzałem ciężkiej artylerii. 5 lutego 1994 roku, w wyniku serbskiego ataku artyleryjskiego, na targu w Sarajewie zginęło 68 osób, a rany odniosło prawie 300. Dnia 9 lutego Francja oraz Stany Zjednoczone, grożąc interwencją zbrojną, zażądały od Serbów wycofania broni ciężkiej spod Sarajewa na odległość 20 kilometrów, a od armii bośniackiej oddania dział pod kontrolę jednostek ONZ. Do akcji tej włączyła się również Rosja, co ostatecznie przekonało Serbów do zaniechania ostrzału miasta. Dzięki temu udało się uniknąć zbrojnej interwencji sił ONZ po wygaśnięciu ultimatum NATO.

W dniu 21 lutego 1994 roku François Mitterrand w telewizyjnym wystapieniu przedstawił powody tej decyzji ${ }^{76}$. Przypomniał, że Serbowie, którzy oblegali Sarajewo, wycofali większość ciężkiego uzbrojenia na odległość 20 kilometrów od miasta. Pozostałe ich siły znalazły się pod kontrolą oddziałów ONZ. Stało się tak dzięki determinacji sojuszników oraz poparciu Rosji. Tym samym wypełniony został pierwszy warunek narzucony przez NATO w dniu 9 lutego. Takie zdanie wyrazili też prezydenci Bill Clinton oraz Borys Jelcyn. Przypomniał, że od początku konfliktu Francja była inicjatorką wszystkich rozwiązań zmierzających do rozwiązania konfliktu, a jej siły zbrojne stanowią największy kontyngent sił pokojowych ONZ. Prezydent przyznał jednocześnie, że pozostaje jeszcze wiele do zrobienia w sprawie Bośni. Chociaż zawieszenie ognia jest przestrzegane, to nie udało się doprowadzić do swobodnego przemieszczania się ludzi oraz transportów z pomocą humanitarną. Mitterrand zagroził, że wszelkie naruszenie decyzji NATO spotka się z odpowiednimi sankcjami. Po raz kolejny opowiedział się za poszukiwaniem rozwiązania na drodze negocjacji oraz zapowiedział, że Francja przedstawi wniosek w Radzie Bezpieczeństwa, by Sarajewo znalazło się pod administracją ONZ. Kończąc swoje wystąpienie, podkreślił, że kon-

\footnotetext{
${ }^{74}$ H. Védrine, Les mondes, s. 655.

75 J. Lacouture, op. cit., s. 411.

$76 \mathrm{http} / /$ www.ina.fr/histoire-et-conflits/autres-conflits/video/CAB94026810/allocution-de-francoismitterrand.fr.html
} 
flikt na Bałkanach dotyczy Francji i przypomniał, że w konflikcie tym śmierć poniosło 18 francuskich żołnierzy, a 281 zostało rannych.

24 kwietnia francuski prezydent wystosował list do prezydenta Rosji Borysa Jelcyna i sekretarza generalnego ONZ Boutrosa Boutros-Ghaliego w sprawie wznowienia negocjacji. O swojej propozycji rozmawiał też telefonicznie z Clintonem i Kohlem. Mitterrand zaproponował zwołanie międzynarodowej konferencji z udziałem Stanów Zjednoczonych, Unii Europejskiej i Rosji w sprawie Bałkanów. Podstawą rozmów miał być projekt przedstawiony przez państwa Unii Europejskiej w listopadzie 1993 roku z inicjatywy Francji i Niemiec, który przewidywał podział Bośni na trzy części: serbską, muzułmańską i chorwacką. Inicjatywa ta spotkała się z pozytywnym oddźwiękiem. 26 kwietnia powstała grupa kontaktowa z udziałem Stanów Zjednoczonych, Francji, Wielkiej Brytanii, Niemiec, Rosji oraz ONZ. Tym samym po raz pierwszy od początku wojny na Bałkanach społeczność międzynarodowa zajęła wspólne stanowisko w sprawie tego konfliktu. Utrudniło to poczynania stronom konfliktu, które do tej pory wykorzystywały rozbieżne interesy głównych mocarstw do własnych celów.

W połowie maja grupa kontaktowa poparła plan podziału Bośni przedstawiony przez Unię Europejską. Plan ten, przypomnijmy, przewidywał przyznanie 51\% terytorium Bośni stronie chorwacko-muzułmańskiej, a 49\% Serbom. Propozycję te odrzucił jednak prezydent Bośni, co spotkało się z ostrą krytyką ze strony Mitterranda. W dniu 3 czerwca powiedział on bośniackiemu prezydentowi: „Jeśli chcecie, by wojna dalej trwała, zablokujcie negocjacje!" 77 . Kiedy ostatecznie Alija Izetbegović zgodził się na przedstawiony mu plan, wtedy odrzucili go Serbowie z Bośni, którzy w tym czasie kontrolowali 70\% terytorium Bośni, chociaż stanowili 34\% mieszkańców tej republiki. Pod naciskiem mocarstw oraz z uwagi na pogarszającą się sytuacje gospodarczą Serbii spowodowaną wprowadzeniem embarga, prezydent Slobodan Milošević odciął się od stanowiska Serbów bośniackich i wprowadził blokadę granicy serbsko-bośniackiej.

W maju 1994 roku Mitterrand udzielił wywiadu kilku europejskim tygodnikom na temat stanowiska Francji w sprawie konfliktu na Bałkanach. W wywiadzie tym odrzucił porównanie wojny w Bośni z wojną domową w Hiszpanii, gdyż w wojnę w Bośni nie były zaangażowane siły zewnętrzne. Sprzeciwił się możliwości zniesienia embarga na dostawę broni dla Bośni w obawie przed dalszą eskalacją konfliktu zbrojnego. Przypomniał, że takie stanowisko wyraziła również Rada Bezpieczeństwa ONZ. Uważał, że była to rozsądna decyzja, tym bardziej, że pojawiły się szanse na uspokojenie nastrojów. Bronił też zaangażowania Francji w pomoc dla Bośni. Podkreślił, że Francja zrobiła więcej niż ktokolwiek inny, gdyż na czternaście tysięcy żołnierzy pokojowych sił zbrojnych stacjonujących w Bośni, aż sześć tysięcy było Francuzami. Rolą francuskich żołnierzy miała być pomoc humanitarna. Zdecydowanie odrzucił możliwość ich udziału w walach zbrojnych. Mówił o tym na początku konfliktu i chociaż był z tego powodu wielokrotnie krytykowany, to zdania nie zmienił.

${ }^{77}$ H. Vedrine, Les mondes, s. 665-666. 
François Mitterrand nie uważał, że konflikt w Jugosławii był porażką Europy. Przypomniał, że Europa nie miała środków, by się mu przeciwstawić w roku 1991. Ponadto Jugosławia była krajem, w którym ścierały się różne europejskie interesy. Nie zgodził się też z oceną tych intelektualistów, którzy oskarżyli go o współudział w zbrodni w Bośni. Po raz kolejny podkreślił, że Francja uczyniła więcej dla Bośni niż ktokolwiek inny ${ }^{78}$.

Pod koniec 1994 roku sytuacja w Bośni nadal była skomplikowana. Rozmowy w sprawie planu pokojowego nie przyniosły porozumienia. W dniu 30 listopada, na zakończenie szczytu francusko-niemieckiego, oba kraje we wspólnej deklaracji wystosowały apel do Narodów Zjednoczonych oraz NATO, by wymusiły przestrzeganie wyznaczonych stref bezpieczeństwa, swobodę poruszania się sił UNPROFOR oraz swobodny dostęp pomocy humanitarnej. Wyraziły też stanowisko, że jedynie pokojowe negocjacje mogą doprowadzić do zakończenia konfliktu i że punktem wyjścia do takich rozmów jest plan pokojowy przedstawiony przez grupę kontaktową. Francja i Niemcy były gotowe wspierać wszelkie starania, by strona serbska zaakceptowała warunki planu pokojowego. Skierowały też apel do państw wywodzących się z byłej Jugosławii o wzajemne uznanie się ${ }^{79}$.

François Mitterrand, mimo pogarszającej się sytuacji na Bałkanach, do końca swojej prezydentury w maju 1995 roku nie podjął decyzji o użyciu sił zbrojnych przeciwko walczącym stronom. Wojna w Bośni trwała do grudnia 1995 roku, kiedy to zawarte zostało porozumienie w Dayton. Na jego mocy kraj został podzielony na część muzułmańsko-chorwacką, która miała stanowić 51\% obszaru państwa i część serbską obejmującą resztę terytorium ${ }^{80}$. Pokój ten nie kończył jednak bałkańskiego dramatu. Wkrótce miał się tam rozpocząć kolejny konflikt zbrojny o Kosowo ${ }^{81}$.

\title{
FRANÇOIS MITTERRAND IN THE FACE OF THE DISINTEGRATION OF YUGOSLAVIA, 1991-1995
}

\author{
Summary
}

The French President, Francois Mitterrand, followed with a great deal of attention a deepening collapse of Yugoslavia in the late 1980s of the 20th century. In the beginning, he believed that thanks to reforms and Serbians it will be possible to maintain Yugoslavia as one country. Mitterrand - as opposed to Kohl, who since the beginning of the conflict supported Croatian and Slovenian expectations of independence - was against a 'wild' independence. This caused a serious conflict in French-German relations dur-

\footnotetext{
78 Wywiad dla „Le Figaro”, 9 wrzesień 1994 r.

79 P. Jardin, A. Kimmel, op. cit., s. 430.

80 J. Kiwerska, Świat w latach 1989-2004, s. 94-96.

81 A. Czubiński, op. cit., s. 398-403.
} 
ing this time. Mitterrand tried to prevent the collapse of Yugoslavia. Finally, in December 1991, France and other members of the European Community, facing a fait accompli by the German side, agreed to acknowledge the independence of all Yugoslavian republics, on the condition that they met specified requirements concerning the observance of human rights, including the rights of minorities. In consequence, the independence aspirations of individual republics became internationally legitimized. It sped up the collapse of Yugoslavia and led to further escalation of fights.

Since the beginning of the Yugoslavian conflict, Mitterrand was in favor of further mediations and against the military intervention of France or the European Community. He did not change his mind until the end of his presidency in 1995 . He believed that one cannot respond with a war for a war. Besides, neither France nor the European Community had sufficient resources to adopt such a policy. He did not, however, see this as a failure of Europe. Mitterrand was in favor of sanctions against the fighting sides, he was ready to support the humanitarian aid. On June 28,1992, he went to the surrounded Sarajevo in order to support the local community. This trip met with a surprise and admiration of almost the whole world. It also brought notable effects. An airlift was opened and this enabled the delivery of necessities for the residents of Sarajevo. Also, the NATO forces, with a mandate of the United Nations, were sent to the Balkans.

Mitterrand's policy toward Yugoslavia was an object of criticism in France by some of French intellectuals who accused the president of supporting Serbians and of showing indifference toward their acts of genocide, above all, in Bosnia. Mitterrand did not agree with these accusations. He stressed that France did more than anybody else for Bosnia. The president's policy toward Yugoslavia was also criticized by the opposition. However, when in 1993 the opposition came to power, despite their earlier promises, they did not introduce a radical change in the French policy in the Balkans. Only the tone of French statements did change. 